A C T A I C H T H Y O L O G I C A E T P I S C A T O R I A Vol. XXI, Fasc. 1

Szczecin 1991

Wawrzyniec WAWRZYNIAK, Edward GRAWIŃSKI

Pathogeny

\title{
AN ATTEMPT DIAGNOSIS OF ETIOLOGY AND PATHOGENESIS OF ULCER AND NECROTIC FOCI OF SOME BALTIC FISHES
}

\section{PRÓBA ROZPOZNANIA ETIOLOGII I PATOGENEZY OGNISK WRZODOWYCH I MARTWICZYCH U NIEKTÓRYCH RYB BALTYCKICH}

\author{
Uniwersytet Szczecinski
}

In the Baltic Sea has appeared a great amount of fishes on which skin observed many anatomicopathological changes of different kind. It caused a realization of the following investigations: parasitological, virological, histological, microbiological and chemical on the presence of havy metal salts, pesticiede and arsenic as a remains of yperite disintegration. The investigations have proved that the direct agents causing diseases in marine environment pollution and the presence of a great amount of bacteria of the genus Areomonas, Pseudomonas, Vibrio, Proteus.

\section{INTRODUCTION}

The Baltic Sea has a chance to become a contaminated and wastefully exploited sea. An alarm signal was the matter of toxic alga, which appeared most probably in consequence of man's activity. The Baltic fishing has been coming down, and fishermen from the Kattegat repeatedly deliver informations about shoals of dead fish and crayfish. Their death is most probably caused by droping level of oxygen in consequence of chemical pollution. This information was transmited by International Ocean Environment Watch the Baltic. An acutely critical period. January 1989.

On the skin of fishes, catching in Polish fishing areas on the Baltic Sea can be observed specific anatomicopathological changes. The agents of these changes as well as the results they can generate have not been specified so far. The intensification of pathological changes was observed in the late seventies and the early eighties, 
mainly in cod and flounder, but in 1981 there was a heavy epizooty of eels (Grawinski, 1982). According to the Sea Fisheries Institute's report from 1984-85 (Lasińska, Rutkowska-Stępień, 1987) in 1982 there were not indicated any distinct regularities in occurence of morbid symptoms of fishes. In cods maximum of morbidity occured in May, when $6.3 \%$ of caught fishes had morbid symptoms. In the next month was observed a sharp drop of pathological changes till $0.93 \%$ in October. On the everage $4.1 \%$ of the cod was found to have ulcerations that year. Ulcerations of herring were between 0.07 and $0.9 \%$ of all the caught. The low level $-0.9 \%$ was observed also in sprats. $0.6 \%$ the caught sprats have been found to show developmental anomaly concerning imperfect forming of operaculum. $1.4 \%$ of the caught flounders have been found to have ulcerations localized on the nonpigmented side of fish. $1.2 \%$ of the caught flounders have been stricken with lymphocytosis and $1.6 \%$ have had disorders of pigmentation. Exceptionally many ell ponts have had ulcerations - $16.8 \%$.

Investigations carried out by Rutkowska-Stępien (1987) shows, that the intensity of ulcerations occurence of industrially fishing Baltic fishes during 1985-86 remains on the same level. In general there was observed a certain drop of ulcerations occurence in comparison with 1983, when the maximum of morbidity was noted.

Most frequently ulcer changes occured on benthic and demersal fishes. Dissemination of ulcerations of cod shows that they occur in the whole Polish fishing area. Observations on seasonal changeability of ulcerations occurrence of cod show its droping tendency. It's conected with appearing of greater amount of ulcerations in autumn. Concerning flounders a similar situation was observed. Interactions between the extensiveness of occurrence of ulcerations of cod and the depth show that the most ulceration changes occured on fishes cauhgt in spring, on the depth from 40 to 80 metres. It's most probably caused by seasonal migration of cod shoals.

Dethlefsen (1989) studing the frequency of occurrence of diseases and lesions on Baltic cod noted skeletal deformations, eye's diseases and tumours being most frequent.

So far the agent causing this changes hasn't been determined as well as their concequences. Using these fishes in food processing, particularly when the agents responsible for pathological changes stay unknown, always carry a risk of infection of man. Infected fishes have shorter time of storage and lower quality. In literature there is a very few publications concerning kind and character of such lesions conected with data about particular marine fish species.

Ulcer disease of cod studied Jansen and Larsen (1979, 1982). They carried out their experiments under artificial conditions observing succeeding phases of ulceration and distinguished five stages, describing them as an "ulcer syndrome". During virological and bacteriological investigations two kinds of virus were found Rhabdivirus and Indiovirus, and bacteria Vibrio anguilarium Jansen, Bloch, Larsen (1979). There were succesfull grafts of microorganisms from ill to in good health fishes, 
which caused the growth of pathological symptoms of the second (Jansen, Larsen 1982, Wawrzyniak, Grawiński 1988). Ulceration changes of cod named by Jansen as an "ulcer syndrome" were classified by Kinne (1984) to virological diseases. Althought studies were carried out on this subject, there is any clear answer about etiology and pathogeny of the ulcer disease.

Knowing there are different reports and oral informations on this subject, many experiments covered by the Fishing and Fishery Service Company "Szkuner" were carried out aimed to define agents originating these diseases and the influence of contaminated fishes on in good health ones.

\section{MATERIAL AND METHODS}

Fishes to study were suppling by fishermen from all the Gdańsk coast. The localities of fishing are shown on figure 1. More observations and experiments were carried out on rainbow trout (Salmo gairdneri Rich.) farming in Puck Bay and on eels which were infected by injection with contaminated serum.

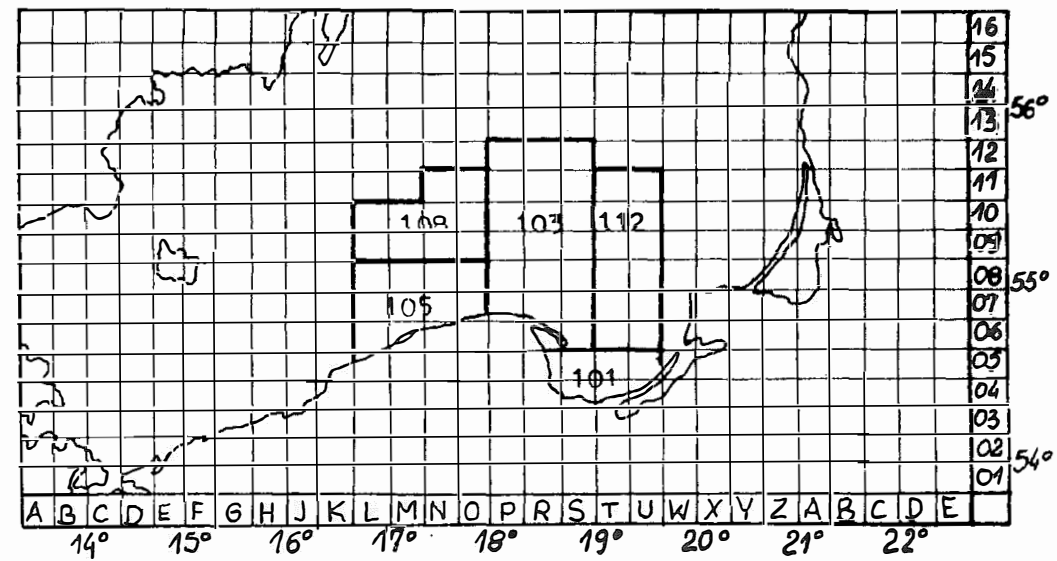

Fig. 1. Regions of fishing of the studied fishes. 101 - Gdańsk Bay, 103 - Władysławowo Ground, 105 - Ustka- Eeba Grounds, 108 - Słupsk Trough, 112 - Gdańsk Deep

The investigations were carried out between 1978 and 1983. To study were caught 600 specimen of cod (Gadus morhua L.) and flounder (Platichthys flesus L.) 90 specimen of salmon (Salmo salar L.) and trout (Salmo trutta L.), and about 1000 specimen of rainbow trout (Salmo gairdneri Rich.) farming in Puck Bay. Infected fishes were selected from a great parts of fishings. The percentage of fish infected was not determined becouse contaminated fishes were turned overboard by fishermen. The six years' studies and observations of infected fishes have showed that the most frequent disease of cod were ulcer foci and limphocytosis of flounder. Observations of these 
Number of fishes with lesions observed during studies from particular fishing grounds

\begin{tabular}{l|c|c|c|c}
\hline \multicolumn{1}{c|}{$\begin{array}{c}\text { Specification of fishing } \\
\text { grounds (s. Fig. 1) }\end{array}$} & Fins erosions & Ulcer foci & $\begin{array}{c}\text { Tumours } \\
\text { (lymphocytosis) }\end{array}$ & Total \\
\hline $\begin{array}{l}\text { Puck Bay } \\
\text { R-6 }\end{array}$ & 48 & 21 & 17 & 86 \\
$\begin{array}{l}\text { Gdańsk Bay } \\
\text { R-4, 5, 6, 7, } \\
\text { S-4, 5, 6 }\end{array}$ & 49 & 70 & 31 & 150 \\
$\begin{array}{l}\text { Ustka-Łeba } \\
\text { N-7, 8, 9; O-7, 8, 9 }\end{array}$ & 26 & 16 & 33 & 76 \\
$\begin{array}{l}\text { Władysławowo } \\
\text { P-7, 8, 9; R-7, 8, 9, 10, 11 } \\
\text { T-12, 13; S-13, 14, 15 }\end{array}$ & 41 & 85 & 3 & 129 \\
\hline
\end{tabular}

changes on particular fish species show the connection between locality of fishing and type of illness (Table 1). The most infected fishes of Gadidae family originated from the Władysławowo Banks and Gdańsk Bay. Flounders with limphocytosis originated the coastal fishing areas of Ustka- $€$ eba and Gdańsk Bay. Observations made during 1982-83 showed that many fish species, cod, flounder, plaice (Pleuronectes platessa L.) and ell-pout (Zoarces viviparus L.) among them had fins erosions in different developmental stages.

In order to know the agents of the diseases mentioned above and to establish if there is any wrong influence of infected fishes on human and animal health the investigations were carried out as follow: parasitological, virological, histological and microbiological. It was tried to found the influence of yperite and radiocontaminations as well as remains of pesticides and heavy metal salts on the development of diseases of the studied fishes. Observations upon lesions in rainbow trout farming in brackish water of Puck Bay were carried out too. Moreover the infected serum of ell (Anguilla anguilla L.) was injected to in good health one.

The classification of observed changes was based on the most characteristic external signs occuring on fishes. The lesions have been divaded into three categories: fins and tail erosions, ulcer foci tumours of skin and fins.

\section{External lesions observed on Baltic fishes-disscusion}

\section{Fins erosions}

First signs of the disease is the redness of soft rays and parts between hard rays of fins. Then appears the losses of parts of soft rays exposing the whole skeletal 
of rays, first upper parts then exposing the whole skeletal of rays till their base. When advanced disease, the process of necrosis includes entire fins with their rays. The pathological changes of cod most often observed on dorsal and tail fins. On flounder the disease covered tail and pectoral fins. The same changes occured also on rainbow trout farming in sea wather. The disease of trout is defined as "fin rot" or "tail rot" (Prost, 1980). The changes are attributed to bacterial infections, mechanical excorations, defective nourishment and too high density of stock. The disease is obserbved on specimen fishing in coastal regions of the Baltic Sea. Existing of the disease is also attributed to the spread of water contamination (Sherwood, Mearns, 1977).

\section{Ulcer foci}

Generally we can assume that the occuring of ulcer foci of fish from investigated localites is not related to the season of year. In the first developmental stages of the disease the pathological changes on cod manifested itself as dermal phologistic spots, mostly around the mouth, operculum and tail. On these places occured the gradually loss of scales followed by epidermis damage. Phologistic process leads to skin necrosis and then to muscles necrosis. Disintegration of musculature caused the creation of ulceral niche (Fig. 2). Ulcer foci of flounder arise mostly on the ventral side. A single focus is mostly spherical in shape, flat or slightly concave. The bottom is dark red and covered with mucus (Fig. 3).

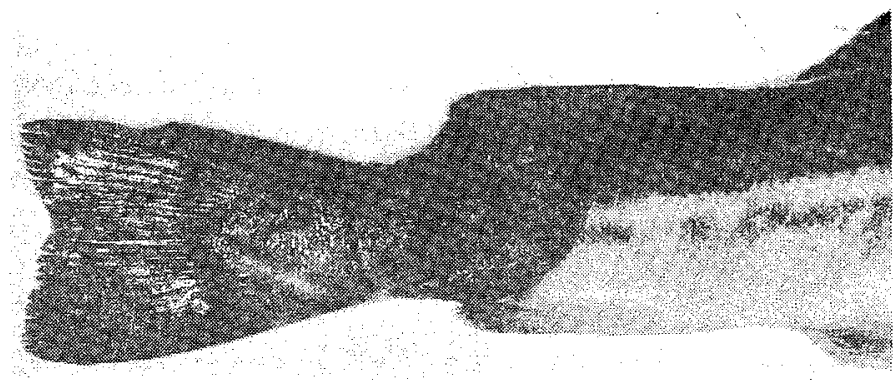

Fig. 2. An ulcer focus on cod

First on the skin of breeding rainbow trout appear the rednesses then form soft swellings with slough and dark cherry-jelly fluid inside. After a few days they burst and become similar the ulcerations occuring on cods. The changes concomitant with strong alimentary canal congestion and death.

Development of the disease of trout was observed continually during its incubative period. It wasn't possible to make such observations under fishing species, mean cod and flounders, but external symptoms as well as flora of bacteria (Table 2) show that they are similar the ulcer disease (Prost. 1980). 


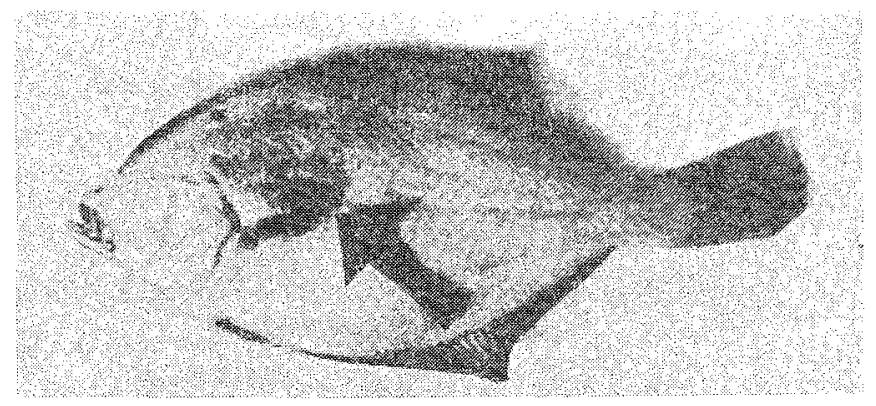

Fig. 3. An ulcer focus on flounder

Table 2

Characteristics of isolated bacterial strains from cod (Gadus morhua L.) flounder (Platichthys flesus L.)

\begin{tabular}{|c|c|c|c|c|c|c|c|c|}
\hline \multirow[b]{2}{*}{$\begin{array}{c}\text { Genus } \\
\text { of bacteria }\end{array}$} & \multicolumn{3}{|c|}{ Cod } & \multicolumn{3}{|c|}{ Flounder } & \multirow[b]{2}{*}{$\begin{array}{c}\text { Sea } \\
\text { water }\end{array}$} & \multirow[b]{2}{*}{$\begin{array}{l}\text { Bottom } \\
\text { muds }\end{array}$} \\
\hline & $\begin{array}{l}\text { tailaand } \\
\text { fins } \\
\text { erosions }\end{array}$ & $\begin{array}{l}\text { ulcer } \\
\text { foci }\end{array}$ & $\begin{array}{l}\text { without } \\
\text { lesions }\end{array}$ & $\begin{array}{l}\text { tailaand } \\
\text { fins } \\
\text { erosions }\end{array}$ & $\begin{array}{l}\text { ulcer } \\
\text { foci }\end{array}$ & $\begin{array}{c}\text { productive } \\
\text { changes on } \\
\text { fins and skin } \\
\text { (limphocytosis) }\end{array}$ & & \\
\hline Alcaligenes & 2 & 0 & 0 & 0 & 0 & 0 & 0 & 2 \\
\hline Aeromonas & 38 & 25 & 3 & 3 & 29 & 49 & 17 & 12 \\
\hline Vibrio & 17 & 40 & 0 & 2 & 3 & 2 & 49 & 37 \\
\hline Pseudomonas & 11 & 10 & 2 & 0 & 17 & 15 & 93 & 3 \\
\hline Xanthomonas & 2 & 9 & 0 & 0 & 8 & 8 & 6 & 2 \\
\hline Flavobacterium & 6 & 28 & 2 & 0 & 0 & 2 & 19 & 3 \\
\hline Moraxella & 11 & 11 & 0 & 1 & 3 & 7 & 15 & 1 \\
\hline Acinetobacter & 7 & 10 & 0 & 0 & 3 & 9 & 5 & 0 \\
\hline Achromobacter & 6 & 3 & 3 & 0 & 2 & 6 & 2 & 0 \\
\hline Enterobacteriaceae & 25 & 30 & 30 & 13 & 21 & 59 & 64 & 22 \\
\hline Unidentificated & 11 & 9 & 4 & 0 & 7 & 10 & 14 & 10 \\
\hline $\begin{array}{l}\text { Number of studied } \\
\text { strains }\end{array}$ & 136 & 176 & 44 & 19 & 93 & 167 & 200 & 92 \\
\hline
\end{tabular}


Tumours of skin and fins- lymphocytosis

This type changes were mostly observed on flounders originated from coastal fishing grounds. Growths of lymphocytosis occuring on fins and skin seeing like small glittering tubercles similar rasberry fruit or cauliflower's warts in shape (Fig. 4).

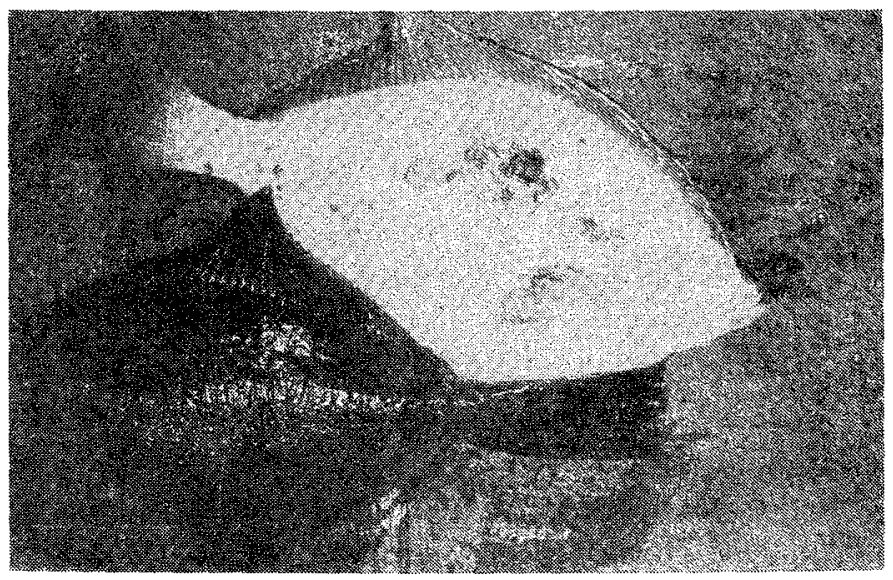

Fig. 4. Lymphocystis disease in flounder from Karwia vicinity

Histological studies showed that these tumours are connected with hypertrophy of skin connective tissue. First thought that the reason of the disease was protozoan of the family Microsporidia. Only in the sixties had been isolated virus causing the disease. Lymphocytosis is mostly prevalent on flounders from coastal waters of the Atlantic. Recently were described in great quantities epizooties of flounders from the North Sea (Weissenberg, 1965; Mann, 1970), the Irish Sea (Shelton, Wilson, 1973) and off the coast of Newfoundland (Templman, 1965).

\section{RESULTS}

The following specialistic studies were carried out at science institutes: the influence of blistering combat agents and radioactive pollution, remains of pesticides and heavy metal salts in muscular tissue, virological and histological studies. The authors coordinated the investigations in order to find if particular factors have any influence on formation previous mentioned pathological changes of fish.

1. The influence of blistering combat agents

According to fishermen, the reasons of external pathological changes on fishes are blistering combat agents suberged there during the second world war and radioactive 
substances of unknown origin. In this connexion the authors applied to the Military Institute of Chemistry and Radiometry in Waarsaw with a request to establish if the reason of pathological changes on fishes was really yperite and radioactive substances.

On of the main characteristic physico-chemical properties of blistering agents is occurence of arsenic, normally not occuring in alife organisms. The methodology is precisely described in the report. Infected and in good health cods and flounders were studied.

According to the measurments were ascertained that the amount of arsenic in places infected is between 4 and $6 \mathrm{mg}$ per $\mathrm{kg}$, while in control material is between 3.5 and $6 \mathrm{mg}$ per $\mathrm{kg}$. This allow to state that detected pathological changes were not generated by the contact with arsenic substances, yperite in this instance. ${ }^{\mathrm{x}}$

Radioilogical measurements of total fish radioactivity showed the low level of radiological contamination. The radioactivity of diseased fishes didn't differ considerably from this of fishes in good health. So it's possible to ascertain that observed pathological changes were caused not by ionizing activity but different factors.

2. Remains of polichromatic pesticides, polichromatic diphenyls and hevy metal salts in muscular tissue

Chemical investigations were carried out at the Department of Veterinary Hygiene in Gdańsk. The study was aimed to quantify of hexachlorobenzene (HCB); $\alpha, \beta, \gamma, \Delta$ hexachlorocyclohexane (BHC); DDT and its metabolites (DDT = DDE+DDD+DDT); polichromatic diphenyles (PCB) and amount of heavy metal salts $(\mathrm{Pb}, \mathrm{Cu}, \mathrm{Zn})$ in tissues of salmon, trout and flounder with pathological changes as well as in good health fish specimen.

Bioaccumulation of synthetic chemical substances contaminating sea environment in fish is a result of absorbing them together with food or absorption from water. The amount of bioaccumulation of a substance is descrobed by ratio of bioaccumulation WB, i.e. relation between its concentration in organism and in received food or in surrounding water. It resulting from settled equilibrium between absorption and excretion.

Studied samples were taken during fish processing from places close to the spinal column. Remains of $\beta, \triangle \mathrm{BCH}$ were not detected, but only remains of DDD, DDT,

\footnotetext{
${ }^{\mathrm{x}}$ After the second world war troops leaving the coastal regions submerged into Polish coastal waters ammunition with yperite. Probably in the late fifties occured package slackness and the sea threw off the shore their remains. As a result many children from summer youth camp and fishermen were blistered on this area. The Department of Fish Disease in Bydgoszcz received cods contaminated by this agent. The every fish had on the ventral side from head to about medium of the body destroyed skin and adjacent to it muscles. Destroyed spots were lack of skin and natured like withered gangrene. It seemed like the fishes during feeding got into contact with the blistering agent. Unfortunately, those days was not allowed to publish information like that, so this information is the first public report. Editor E. Grabda.
} 
$\mathrm{HCB}$ and PCB. The quantities of compounds listed above were as following: the amount of PCB from 3.5 to 9.5 times exceeded the amount of DDT, and ratio PCB/DDT was the high the longer fish. The amount of fat in muscle tissue of salmon and trout was from $0.81 \%$ to $5.2 \%$. The correlation ratio between the lenght of fish and amount of particular substance in fresh tissue was as following: $\mathrm{HCB} r=0.49 ; \alpha-\mathrm{BCH} \mathrm{r}=-0.42$; $\gamma$ BHC $=-0.59$; pp-DDE $r=0.44$; pp-DDD $r=-0.18$; pp-DDT $r=-0.24$; PCB $r=0.51$ When calculated on fat mass the correlation ratio was as following: $\mathrm{HCB} \mathrm{r}=0.33$; $\alpha$-BHC $r=-0.4 ; \gamma-B H C r=0.49$; DDT $r=0.14 ; \mathrm{PCB} r=0.46$. According to the results, there is a certain increase tendency of HCB and PCB in muscle tissue of salmon and trout with the growth of fish lenght.

Results of studies on quantity of $\mathrm{Pb}, \mathrm{Cu}, \mathrm{Zn}$ in muscle tissue of flounder, show that quantity of this metals has increase tendency to data described by Bochosiewicz (1980).

According to the represented above results can be drowed a conclusion that there is no immediate realation of studied factors on development of pathological changes of fish, becouse the amount of previous listed compounds was the same in diseased as well as in good health fishes. These factors can have only indirect influence on previous described pathological changes, causing weakness of fish organism.

\section{Virological studies}

Opinions that anatomicopathological changes abserved on fishes may exist as a result of virological infection caused that exact studies were carried out. The studies were carried out at the Laboratory of Virology of the Institute of Sea and Tropical Medicine in Gdynia.

The diagnostic studies were carried out on chorion-allantois membranes of 12-13 days old hens embryos. Infected embryos were incubated in $36^{\circ}$ centigrade and in room temperature, every experiment was carried out on five embryos. The control made uninfected embryos incubated in the same time. Simultaneously carried cultivation on tissues of primary kidney cells of monkey.

Obtained results of virological studies were negative, but we can't exclude virological etiology of the diseases of Baltic fishes described above. There are known cases that virus isolated naturally infected organism can not well develop under experimental conditions. Virological specificity to host is regulated genetically by its characteristics in very specific way. The more so as in the culture of virus lacked fish cells. There is lack of data which could suggest the possibility of breeding diseases of man by accidental consumption of infected fish. 


\section{4: Histological studies}

For complete appreciation the observed changes of fish histological studies of changed skin, fins and muscules were carried out. The fish were examined at the Department of Veterinary Hygiene in Gdańsk.

The changes of cods' and flounders' fins while erosions occuring showed development of cells typical for inflammation of tissue. When widespread the infammation changes were observed passing from fins to musculature, discovered phologistic infiltrations composed of onenucleus cells, which covered surface layer and deeper muscules.

Ulcer foci of cod contained one- and multinucleus cells with erytrocytes and mass of fibrin in addition, and slough sometimes. The bottom of ulcerations was mainly covered with necrosed thrombus and their edges were created with granulation. Ulcer foci of flounder like these of cod were characterized by changes within epidermis, hypodermic tissue and many times by changes within musculature as diffuse infiltratrion composed of granulocytes and onenucleus cells. Some places the infiltration was composed of abundant granulation built up with numerous masses of fibrins and netrual absorbing granulocytes.

The productive changes of lymphocytosis of flounder showed histologically hyperplasia of epithelium, focal phologistic infiltration and numerous lymphatic cysts with foci of calcification. Stomach, spleen and gonads were heavy congested while liver showed congestion and small-droplet steatosis of cells.

The authors' studies were carried out at the Department of Veterinary Hygiene in Gdańsk and at the Experimental Centre of Trout Farming in Kuźnica. They concerned parasitology, microbiology and observations on development of the disease of farming rainbow trout. Experiments with injection of serum from diseased eels to in good health ones were carried out too.

\section{Parasitological investigations}

Parasitological investigations of fishes with visible pathological cutaneus changes showed:

Inside end's part of large intestine of flounder found an acanthocephalon Pomphorynchus laevis in $67.7 \%$ of examined fishes, inside small intestine found a nematode Thynascaris adunca in $11.1 \%$ of examined fishes, whereas in lens found metacercaria of Diplostomum spathaceum in $47.9 \%$ of examined fishes.

Cods with or without pathological changes were found to be infected with an acanthocephalon Echinorhynchus gadi in $100 \%$. Degree of infection was different with the advantage of higher intensity when fish had pathological changes. 
The investigations showed that the changes occuring on examined fishes are not caused by parasites, whereas comparing fishes in good health to diseased ones it results that fishe, with visible external anatomtomicopathological cutaneous changes are more infected with parasites. It may be explained as a result of fish weakness and higher susceptibility of infection. The above studies ivere confirmed by Waluga, Własow, Dyner, Świątecki (1986). Additionally these authors ascertained high intensity of microsporidia of the genus Pleistophora and Eimeria macroresidaualis.

\section{Microbiological investigations}

Microbiological investigations consisted in isolation, identification and biochemical differentiation of bacteria coming from cod's and flounder's pathologically changed tissues. In comparison bacterial flora from unchanged fishes was studied. Every isolation of particular genus of bacteria made during study. Identification of obtained bacterial strains made in order to determine their attachment to particular genus. An amount of particular types of strains occuring in fishes, in sea water and bottom mud have presented in table 2 .

It's been determined that in cod's erosions most frequently occured bacteria from the following genus: Aeromonas, Vibrio, Moraxella and Enterobacteriaceae which may be undoubtly conected with high water pollution. Bacterial flora of flounder's erosions was as following: Aeromonas, Pseudomonas and Enterobacteriaceae. Investigations of sea water and bottom mud's showed that dominant factor of contamination are bacteria of the genus Enterobacteriaceae, Vibrio, Aeromonas, Moraxella and Flavobacterium (Table 2).

The bacterial flora occuring in studied fishes is typical for water environment. Bacteria of type Aeromones, Pseudomonas, Vibrio can however cause under specific conditions diseases of fish and other water animals (Prost, 1980; Amlacher, 1986). Some bacteria strains can provoke intoxication, especially of children, after consuming fishes excessively contaminated by Pseudomonas aeruginosa and Aeromonas hydropila.

The investigations of musculature tissue of cod with pathological changes have showed the mean amount of bacteria range $6.44 \times 10^{2}$ per 1 gram of tissue. Rise of amount of bacteria was observed also in inoculations from the tissue of fishes in good health (cods), it reached meanly $5.15 \times 10^{2}$ per 1 gram of tissue, which is proof that the tissue was not complety aspetic. Probably, the studied fishes had damaged selfdifense system, which was caused by high contamination of water with chemical compounds and considerable excess of bacteria in water. 


\section{Observations about pathological changes}

The changes similar these of cods and flounders were observed on experimentally farming rainbow trouts. Trouts were farming in live boxes in Puck Bay, what simplifacated observations under development of disease, the occurrence of external changes and their behaviour. Internal investigations it is dissections of farming fishes have been done as well as microbiological studies of the fishes, sea water and bottom mud.

The fishes with lesions have been observed to have locomotive disorders. The fish swam up to the water surface and ranged itself a little aslant in the body line all the time intensely moving opercula and mouth. Later after five to twelve hours the fish leant aside and layed in such position in the water. When disturbed swam away being aside and struck against net of the live box. The diseased fis after twenty four to forty eight hours completely losted the balance swiming vertically or horizontally, then slowly fell down on the bottom of live box and died.

External lesions on these fishes manifested gradually. First appeared redness of skin around dorsal and pectoral fina, mouth, anus then appeared the white ends of dorsal fins and tail. After five to ten days, on the dorsal side, started to appear soft swellings which, when fish was still alive, opened. These external lesions accompanied exophthalmus.

The dissectioned fishes with lesions mentioned above were observed to have congestions of internal organs with numerous spot ecchymosis. The congestions were observed on gonads, liver, intestine and abdomen lobes. Besides spleen and kidney enlargement was observed. The lesions accompanied catarrh of intestinal tract with heavy congestion mainly of its end's part. When a lot of fishes were dead, during dissections in their stomachs occured an yellowish tremellose fluid. Sometimes the fluid fielled a body cavity. The fluid as well as vitreous body contained a great number of gas bubbles. The dead fishes had also lighter inflammable changes of inner organs, without distinct cutaneus changes. But every dead fish had the white ends of dorsal fins and tail and heavy congestion of end's part of intestine.

Histological studies of intestine showed congestion of mucous membrane and infiltration of onenucleus cells (granulocytes and leucocytes). Similar infiltrations detected on gills of dead fishes, which affirmated heavy inflammable process.

At the same time together with anatomicopathological studies carried out microbiological investigations of fish and environment. It's been showed that in sea water and bottom mud dominated bacteria of the genus Aeromonas, Pseudomonas, Vibrio, Enterobacter, Citrobacter Coli, Proteus, Kleibsiella. In studied trout's organs identified the same bacterial genus as in sea water and mud. In the intestinal tract of studied fishes detected an advantage of bacteria of the genus: Enterobacteriaceae to Aeromonas, Vibrio and Pseudomonas, whereas in other organs and advantage of bacteria of the genus: Aeromonas, Vibrio and Pseudomonas. The organs which had the 
highest amount of bacteria were gills, fins, stomach and intestine. In muscles of farming trout, like in cods, detected bacteria of the genus: Aeromonas, Vibrio, Pseudomonas, Coli and two unidentificated strains. In blood of farming trout also detected bacteria of the genus Aeromonas, Pseudomonas, Moraxella and three unidentificated strains. Presence of bacteria in the blood and muscles confirmed that had occured damage of natural selfdifense processes of fishes.

\section{Experiments with injection the serum of diseased fishes to in good health ones}

Observed symtoms of disease of farming trouts as well as progressive diseased stages induced the authors to carry out an experiment to testify pathogenous character of some bacterial strains. It was carried out on eels in three series.

Into cement basins of the capacity of one cubic meter each, with current water of constant temperature ranged from 7 to $10^{\circ} \mathrm{C}$ were placed 5 eel specimen in good health weighted from 200 to 300 grams. Into one basin were put fishes injected petrinoeally with the broth filtrate of bacteria of the genus Aeromonas, Vibrio and Pseudomonas. The dose was 0.5 cubic centimeter per one fish. Into the other basin were put fishes in the same form and weight as into the first basin which injected with the same filtrate and dose but intramuscularly. The detailed observations of eels made every day. After 2-3 days on fishes injected petrinoeally observed redness of base of pectoral, dorsal and anal fins, on the whole body appeared spotlet rednesses. After 4 days occured redness around mouth and obliteration of mucus on the skin. On the fifth day in the places with redness observed swellings and fractures of blood-vessels and formation of ulcer foci (Fig. 5). The form of fishes was less and less weak and after 8-10 days the fishes dead. The dead eels were disectioned, there was stated the occurrence of the yellowish tremellose fluid and haevy congestion of petrinoeum membrane, mucous membrane, stomach, intestine and liver. The enlargement of kidney was observed too. Microbiological studies of tissues and organs showed the presence of bacteria of the same biochemical features as the bacteria which fishes were infected with. Development of lesions of eels injected intramuscularly was the

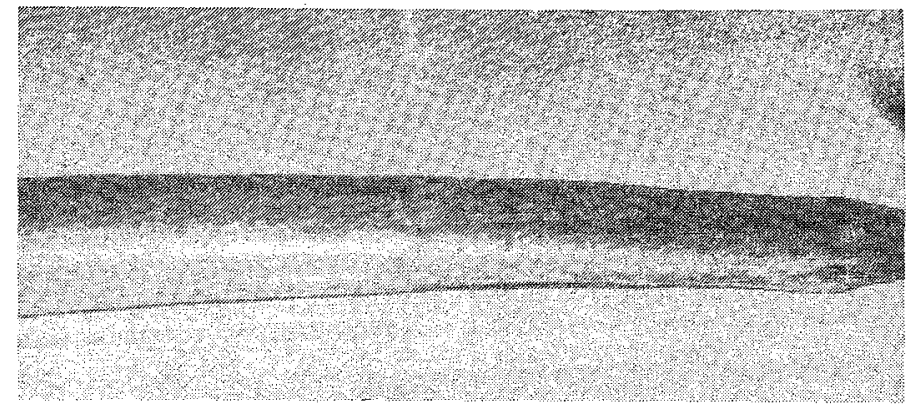

Fig. 5. An ulcer focus on eel created after peritoneal injection 
same as of eels injected peritoneally. Only the period between injection and death was longer and figured from 10 to 14 days.

\section{CONCLUSIONS}

The investigations carried out and described above were an exploration aimed to determine agents of formation the lesions of living in the Baltic fishes. A brief discussion of the results of our studies termed which of the exploring lines should be broaden in aim to explain the reasons of lesions of the fishes.

Presented descriptions of the disease of trout and microbiological studies suggest that we can accord with opinions that development of the disease of trout is progressive. It started with rednesses, mean symptoms similar these of bacterial infection by Pseudomonas. Progressive development of the disease cause the ill of fins (fin rotbacteriosis pinnarum) observed on studied fishes as erosion of fins caused by bacteria of the genus: Aeromonas and Pseudomonas, which ended turning into ulceration (furunculosis salmonum - of salmon fishes) occuring in acute or chronic form. The presence of mentioned above strains was detested during microbiological studies (Table 2) on trout and other tasted fishes.

The experiment carried out on eels showed very similar development of the lesions as these on trout. The lesions of eels injected with the broth filtrate were similar these of trouts, cods and flounders. So we can assume that reason of the illnesses of these fishes is similar. The above studies had been confirmed by Waluga, Własow, Dyner, Świątecki (1986), added that the agent of these illnesses may be Pleistophora $s p$. , too. The picture resulting from the studies showed that bacteria of the genus Aeromonas, Pseudomonas, Vibrio, Proteus, Moraxella and Coli most probably take part in pathological symptoms. In order to determine more precisely species responsible for the lesions further studies are required.

Virological experiment showed that using methods described any virus didn't develop. These methods are using to multiply great quantities of virus of warm-blooded animals. So we may suggest if the virus responsible for the lesions occured in the fishes, they don't develop into warm-blooded organisms.

Occurrence of pesticides and haevy metal salts don't exert direct influence on the development of lesions. But they can exert an indirect influence causing weakness of the organism. Similar conclusions issue from parasitological investigations. They show that fishes with considerable anatomicopathological changes are far more parasited.

Studies concerning iperite and radioactive pollution showed that they don't have any direct influence on the development of anatomicopathological changes of tasted fishes. 
Microbiological investigations, the experimental injection with the broth filtrate of bacteria of the genus: Aeromonas, Vibrio and Pseudomonas to in good health eels and observations under farming trouts showed that development of the disease is progressive, from spoted rednesses of fins to well distinguishable anatomicopathological changes on skin ending with death. The investigations show that the pollution of environment and a great amount of bacteria occuring in it causing a weakness of fish and provoke a development of the previous described diseases. Bacteria, which most probably causing the development of the diseases of studied fishes belong to the following genus: Aeromonas, Psedomonas, Vibrio, Proteus, Moraxella and Coli. The experiment with injection of the eels' infected serum to warm-blooded organism was not carried out. Knowing the negative influence of pollution on human organism it's much safer not to use fih with visible anatomicopathological changes for processing and direct consumption, becouse they can be a reason of an infection of men. From literature and medical practise we know that some bacteria species from strains mentioned can cause diseases of man.

\section{REFERENCES}

Almacher E., 1986: Taschenbuch der Fischkrankheiten. VEB Gustav Fischer Verlag. Jena.

Bochosiewicz M., 1980: Wpływ zanieczyszczeń środowiska metalami na zdrowie zwierząt i środki spożywcze zwierzęcego pochodzenia. [The influence of environment pollution with metals on animal health and food products of animal origin]. Życie Weterynaryjne 8/80, LV: 231-232. (in Polish).

Dethlefsen V., 1989: Krankheiten des Dorsches (Gadus morhua L.) der Ostsee. Fischirtsch. Z. 2: 62-63.

Grawiñski E., 1982: Charakterystyka mikrobiologiczna węgorza ze zmianami patologicznymi poławianego w 1981 roku w Zatoce Puckiej i Zatoce Gdańskiej. [ The microbiological characteristic of eel with lesions fishing in Puck Bay and Gdańsk Bay, in 1981]. Biuletyn MIR 1-6: 14-16. (in Polish).

Jansen N.J., B. Bloch, N.J. Larsen, 1979: The Ulcus - Syndrome in Cod (Gadus morhuna L.). III. A preliminary virological report Nord. Vet - Med. 31: 436-442.

Jansen N.J., J.L. Larsen, 1982: The Ulcus - Syndrome in Cod (Gadus morhua L.) IV. Transmission Experiments with two Viruses isolated from Cod and Vibrio anquillarium Nord. Vet - Met. 34: 136-142.

Kinne O., 1984: Diseases of Marine Animals. Biologische Austalt Helgoland. Vol. IV, Part 1. Hamburg. FRG.

Lesiñska K., J. Rutkowska-Stępień, 1987: Zewnętrzne objawy patologiczne oraz stan zapasożycenia niektórych gatunków ryb. [The external pathological symptoms and quantity of parasites of some fish species]. Raporty MIR. 1984-1985. Gdynia.

Mann H., 1970: Über den Befall der Plattfische der Nordsee mit Lymphocystis. - On the lymphocysttis disease in flat fish of the growth of fishes. Ber. Deutsch Wiss. Komm. Meeresforschung: 219-223.

Prost M., 1980: Choroby ryb. [Diseases of fishes]. PWRL. Warszawa. (in Polish).

Rutkowska-Stępien J., 1987: Wpływ zmian wrzodowych na ocenę stanu zdrowotnego użytkowych gatunków ryb bałtyckich. [The influence of ulcer changes on the appraisal of health condition of usable Baltic fish species]. Biuletyn MIR. 3-4: 23-27. (in Pnlish).

Shelton R.G.J., K.W. Wilson, 1973: On the occurence pathological conditions in the flatfish Stocke of the north Iris Sea. Aquaculture. 2: 395.

Sherwood M.J., A.J. Mearns, 1977: Environmental significance of fin erosion in Sonthern. California clemersal fishes. Annals New York Academy of Sciences. 290.

Templeman W., 1965: Lymphocystis Disease in American Plaice of Eastern Grand Bank. J. Fish Res. Bd. Can. 22: $1345-1356$. 
Waluga D., T. Wlasow, E. Dyner, A. Swiątecki, 1986: Studies on the etiopathogenesis of fish diseases in the Baltic Sea. Acta Ichthyol. et Pisc. XVI, 2: 53-72.

Wawrzyniak W., E. Grawiński, 1988: Próba określenia przyczyny powstania zewnętrznych zmian anatomopatologicznych występujących u ryb bałtyckich. [An attemt to define the reason of externai anatomicopathological changes occuring on Baltic fishes]. Biuletyn CLPR. 5-18. (in Polish).

Weissenberg R., 1965: Fifty years of Research on the lymphocystic Virus Disease of Fishes. Ann. N. Y. Acad. Sci. 126: $362-374$.

Translated: D. Romuk-Wodoracki

\section{Wawrzyniec WAWRZYNIAK, Edward GRAWIŃSKI \\ PRÓBA ROZPOZNANIA ETIOLOGII I PAROGENEZY OGNISK WRZODOWYCH I MARTWICZYCH U NIEKTÓRYCH RYB BA£TYCKICH}

\section{STRESZCZENIE}

W Bałtyku pojawiła się znaczna ilość ryb, na skórze których zaobserwowano różnego rodzaju zmiany anatomopatologiczne. Ryby do badań pobierano $\mathrm{z}$ całego wybrzeża gdańskiego (ryc. 1). Do badań pobierano ryby zdrowe i ryby chore w celach porównawczych, takie jak dorsze (Gadus morhua L.), stornie (Platichthys flesus L.), tososie (Salmo salar L.), trocie (Salmo trutta L.). Powstanie zmian chorobowych obserwowano u hodowanych eksperymentalnie pstrągów tęczowych (Salmo gairdneri Rich.) i węgorzy (Anguilla anguilla L.). Obserwowane zmiany podzielono na trzy rodzaje: nadżerki płetw, ogniska wrzodowe i narośla na skórze i płetwach - limfocystoza. W celu wyjaśnienia przyczyny powstania tych zmian przeprowadzono szereg badań: parazytologicznych, wirusologicznych, histopatologicznych, mikrobiologicznych oraz chemicznych na obecność soli metali ciężkich, pestycydów i arsenu jako pozostałości rozkładu iperytu. Badania wykazały, że bezpośrednią przyczyną powstania schorzeń jest zanieczyszczenie środowiska morskiego, a wraz znim występowanie dużej ilości bakterii z rodzaju: (Aeromonas, Pseudomonas, Vibrio, Proteus, Moraxella i Coli.

Badania potwierdziły również, że ryby ze zmianami chorobowymi są podatniejsze na większe zapasożycennie, natomiast duża ilość bakterii oraz szczepów bakteryjnych wskazuje, iż bezpieczniej nie używać ryb $z$ widocznymi zmianami anatomopatologicznymi do przetwórstwa i bezpośredniego spożycia.

Authors' address:

Received: 1990.04.02

Dr Wawrzyniec Wawrzyniak

Katedra Ekologii, Uniwersytet Szczeciński

ul. Felczaka 3a, 7 71-412 Szczecin

Dr Edward Grawiński

Państwowy Zakład Weterynaryjny

ul. Kaprów 10

80-316 Gdańsk-Oliwa

Polska (Poland) 